Contents List available at RAZI Publishing

\title{
EVALUATION OF BRUSH WOOD WITH STONE CHECK DAM ON GULLY REHABILITATION
}

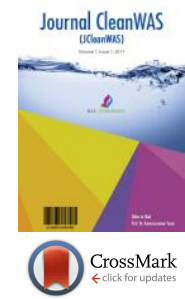

\author{
Obsa Adugna*, Dereje Alemu \\ ${ }^{*}$ Natural Resources, Wollega University Nekemte, Ethiopia. \\ ${ }^{2}$ Environmental, Addis Ababa University, Ethiopia.
}

*Corresponding Author e-mail: obsaadugna82@yahoo.com

This is an open access article distributed under the Creative Commons Attribution License, which permits unrestricted use, distribution, and reproduction in any medium, provided the original work is properly cited

\section{ARTICLE DETAILS}

\section{Article History:}

Received 5 July 2017

Accepted 5 October 2017

Available online 3 November 2017

Keywords:

Gully, soil loss, brush wood

\section{ABSTRACT}

Gullies are common features throughout the Ethiopian Highlands. Induced environmental degradation comprises not only the loss of soil volume and of arable lands, but also the triggering of landslides or off-site sedimentation problems. This experiment was initiated with the aim of evaluating the effect of brush (bamboo) wood with stone check dam on soil and water conservation (gully rehabilitation) at Benishangulgumuz region of Assosa zone (Assosa district of selga-19 for two consecutive research years (2013/14-2014/15) on farm land. The gully site was selected purposively based on the prevalence of gully erosion. Biophysical and socio -economic data were collected from the gully and participant farmers to evaluate the effectiveness of the measures. The potential of the check dam to conserve the soil was evaluated by using the pin installed in front the check dam to observe the change of gully depth, cross sectional area and soil loss data were collected. A total of 22 households were sampled to assess the perception, acceptance and adoption level of the farmers using simple random sampling technique. the result indicates that the gully depth and volume of soil loss, were reduced from $0.94 \mathrm{~m}$ to $0.58 \mathrm{~m}$ and volume of soil loss from 468 ton/ha/yr to 204 ton/ha/yr. The interviewed farmers response also indicated that, all (100\%) of them were mentioned the presence and severity of soil erosion on their farm land and which is increasing from time to time in alarming rate and where all of the farmers mentioned loss of fertile top soil and in turn yield reduction as its integral effect. $95.5 \%$ of the farmers were confident enough to rehabilitate the gully using bamboo with stone check dam by supplementing with other biological measures and all (100\%) of the farmers ratified the effectiveness of the measures to rehabilitate the gully and willing to implement on their farm land thereby to disseminate the technology to non- participant farmers.

\section{INTRODUCTION}

Land degradation, comprising degradation of the natural vegetation cover, soil erosion, loss of soil fertility and moisture stress is a well-known problem in Ethiopian highlands. Land degradation, particularly by water erosion, is an important factor in both the long-term decline and the seasonal reduction in food crop production [1]. Soil erosion in Ethiopian Highlands degrades the soil resources on which agricultural production are based. This threat stems from the depletion and degradation of the vegetation cover of the country, especially forests, and exploitative farming practices.

Gullies are common features throughout the Ethiopian Highlands. Induced environmental degradation comprises not only the loss of soil volume and of arable lands, but also the triggering of landslides or off-site sedimentation problems. The phenomenon of gully development is not restricted to Highlands of Ethiopia, but seems to be a phenomenon on subcontinental scale in Africa [2].

Recently, EIAR (Ethiopian Institute of Agricultural Research) financed soil and water management and/or conservation research has been initiated and in this work an endeavour has been made to identify and characterize indigenous soil and water conservation materials and practices in the Metekel zone with the aim of making recommendations based on the research findings and launching further research interventions [3]. In the assessment, it has been found out that farmers in the area have various agronomic practices like (shenna, intercropping, crop rotation); and vegetative materials (Nechsar, Dagalla, kollasembelet and others) used for soil and water conservation and gully rehabilitation, which could further be improved and/or augmented with other practices for gully rehabilitation (brush wood check dams) and materials for soil conservation on farm lands such as Vetiver grass (Vetiverzizanoides) hedges.

Vetiver occurs in many countries throughout the world [4]. It is introduced to Ethiopia in the 1960's. Vetiveris not site specific, it grows in a wide variety of soils and climatic conditions, it is easy to establish, it is not time consuming, a larger kilometre can be established within a season, very effective and cheaper, it can with stand livestock browsing and trampling [4]. It is promoted as a strategic soil conservation measure in some parts of the country in an effort to halt soil erosion and land degradation (TessemaChekun, ND). The grass is used for rehabilitation of gullies, road cuts and drains stabilization, river bank protection, watershed rehabilitation for dam side protection,forage, wet land protection, and income generation for Schools (Alemu Mekonnen, ND).

Therefore, this experiment was initiated with the aim of enhancing the awareness of the farming communities and evaluating the effect of different physical and biological measures of gully rehabilitation.

\subsection{Objective of the study}

[? To evaluate the effect of brush wood with stone check dam on soil conservation

[? To create awareness among the farmers on gully rehabilitation

\section{MATERIAL AND METHOD}

\subsection{Description of the study area}

The study was conducted at the Assosa Agricultural Research Center 
(ASARC), which is located in Assosa District at Benishangul-Gumuz Regional State (BGRS). The ASARC is located in the western part of Ethiopia from 10o $01^{\prime} 25^{\prime \prime}$ to 10 02 ' 50" north latitude and from 34을 $33^{\prime}$ $50^{\prime \prime}$ to $34^{\circ} 34^{\prime} 35^{\prime \prime}$ east longitude. The study area covers a total land area of 202.5 ha with geologyof Tarmabe basalt, sometimes porphyritic of the Miocene to Pliocene period. The Assosa District is characterized by hot to warm moist lowland plain with uni-modal rainfall pattern. The rainy season starts at the early May and lasts at the end of October with maximum rainfall in the months of June, July, and August. The total annual average (2000-2007) rainfall is $1316 \mathrm{~mm}$. The annual mean minimum and mean maximum temperatures of the District for the periods from 2000 to 2008 were 16.75 and $27.92{ }^{\circ} \mathrm{C}$, respectively. The soil type of the study area was characterized as Nitisol.

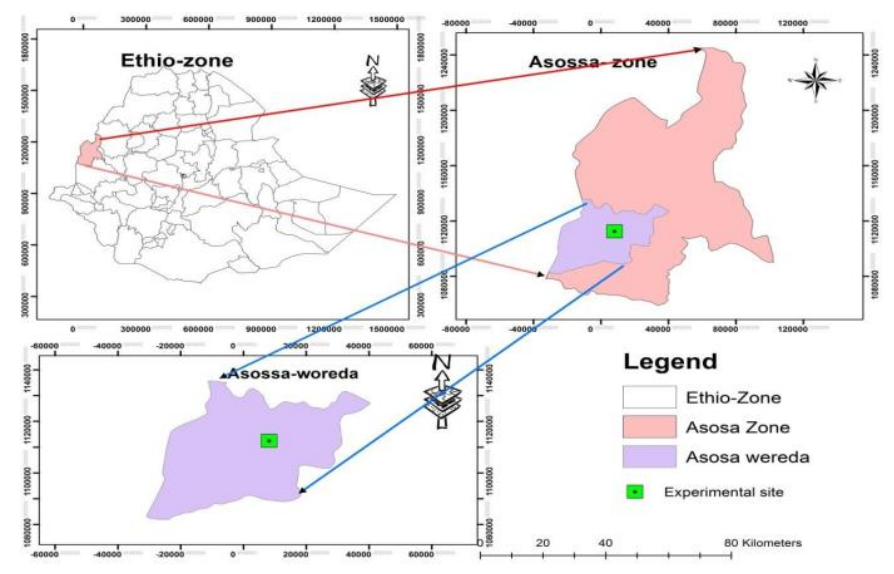

Figure 1: Location map of experimental site

\subsection{Methodology}

The study area was selected purposively with different stakeholders (Farmers, kebele administration, DAs and weed natural resource experts) based on prevalence of gully erosion and accessibility as a criterion for site selection [5]. A group of farmers which has 10-15 members were established to handle the gully research experiment. Training programs were organized for different stakeholders prior to start the experiment on causes of gully formation, management/rehabilitation of gullies and utilization of gullies. The gully was treated with bamboo with stone check dams, and different biological materials depending on the agro ecology and accessibility of the selected sites.

\subsection{Data collection}

The width and depth of the check dam were decided based on the types of gullies that exist in the area on the first year of the activity. Gully cross section area, gully depth, and width were measured before and after the implementation of the gully rehabilitation measures to evaluate and determine the rate of soil loss.

\subsection{Household survey}

Socioeconomic status of the participant farmers such as gender, wealth, age, education, perception of land degradation and mitigation solutions were collected through structured questioner.

\subsection{Soil sampling}

Composite soil samples from two depths 0-15 were collected before and after the experiment from the gully site [6]. Replicated soil samples from the upper, middle and lower parts of the hedgerows were collected at the end of the experiment for soil $\mathrm{pH}$, organic $\mathrm{C}$, total $\mathrm{N}$, available $\mathrm{P}$ and exchangeable $\mathrm{K}$ determination.

\subsection{Soil sample preparation}

Prior to the analysis, the soil samples collected from were air dried, ground and sieved to pass through $2 \mathrm{~mm}$ size sieve in preparation for laboratory analysis of most soil physical and chemical properties. The soil samples were further sieved to pass through a $0.5 \mathrm{~mm}$ size sieve for the analysis of total nitrogen. The specific laboratory procedures followed in the analysis of the respective soil physical and chemical properties are briefly outlined below.

\subsection{Analysis of soil chemical properties}

The $\mathrm{pH}$ of the soil was measured potentiometrically using a digital $\mathrm{pH}$ meter in the supernatant suspension of 1:2.5 soil to water ratio. Organic carbon was determined following the Walkley Black wet digestion method as described whereas the Kjeldahl procedure was followed for the determination of total nitrogen. Available phosphorus was determined by the Olsen procedure. In the Olsen procedure, the soil samples were shaken with $0.5 \mathrm{M}$ sodium bicarbonate at nearly constant $\mathrm{pH}$ of 8.5 in 1:20 of soil to solution ratio for half an hour and the extracts were obtained by filtering the suspension.

\subsection{Statistical analysis}

The collected raw data were systematically coded and analysed using descriptive statistics using Statistical Package for Social Sciences (SPSS) version 20.0 for the household survey and presented with the help of series of tables, and charts.

\section{RESULT AND DISCUSSION}

\subsection{Biophysical data}

\subsubsection{Rainfall distribution of the experimental site}

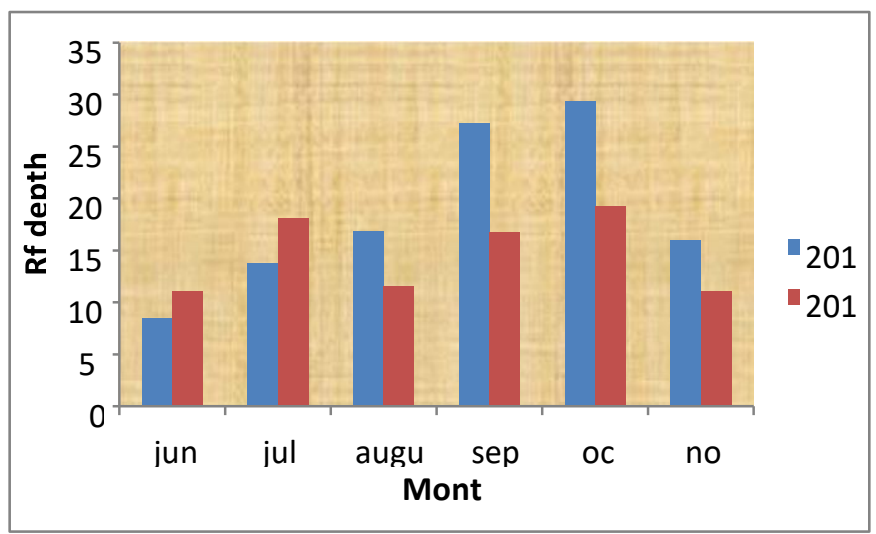

Figure 2: Rainfall distribution (in $\mathrm{mm}$ )

The amount and distribution of precipitation that causes runoff varied during this 2- year study. Table 1 shows the monthly distribution of rainfall at the experimental sites. During the season, annual rainfall that causes runoff in 2013 and 2014 was 1161.8, and $877.8 \mathrm{~mm}$ respectively.

\subsubsection{Gully depth related data}

The change in depth of the gully is the key parameter to evaluate the efficiency of gully rehabilitation measure. Based on this, data of depth of the gully were collected monthly in the rainy seasons of 2005/06 and 2006/07.

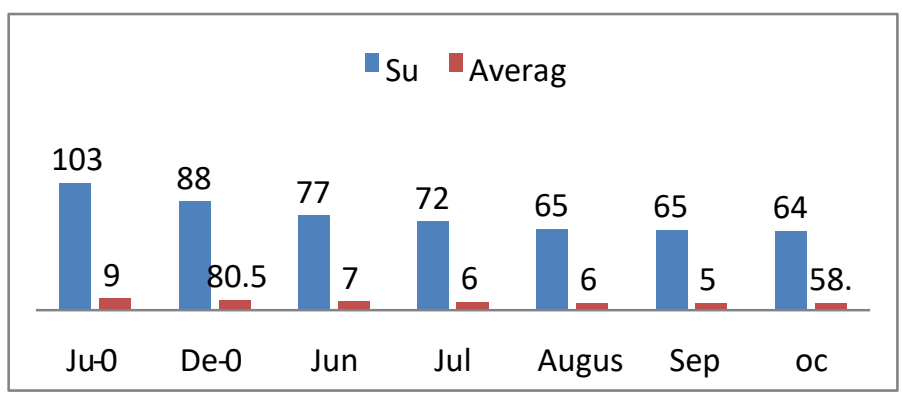

Figure 3: Average and sum of gully depth at selga-19 since 2005/06.

As the above figure shows, the intervention of brush wood with stone check dam had brought great change. The initial average depth of the gully before intervention was $0.94 \mathrm{~m}$ and reduced to $\mathbf{0 . 8 0 5 m}$ at the end (after intervention) of the rainy season of first year (December 2006). On the second research year, the structure had brought the change from $\mathbf{0 . 8 0 5 m}$ to $0.58 \mathrm{~m}$. Totally, using brush wood with stone check dam had reduced the depth of the gully from $\mathbf{0 . 9 4} \mathrm{m}$ to $\mathbf{0 . 5 8 m}$ since its intervention.

3.1.2 Cross sectional area of gully

Cross sectional area is also another key parameter to determine the 
amount of soil loss from the gully. Its length was $\mathbf{2 5 3} \mathbf{m}$ from head to base with drainage area of $2.5 \mathrm{~h}$. The bulk density of this gully was $1.08 \mathrm{ton} / \mathrm{m}^{3}$.

Table 1: Cross sectional area \& soil loss in average at selga-19.

\begin{tabular}{ccccc}
\hline $\begin{array}{c}\text { Collected } \\
\text { Parameter } \\
\mathrm{s}\end{array}$ & $\begin{array}{c}\text { One year } \\
\text { after impl. } \\
\text { (June } \\
2005 \text { ) }\end{array}$ & $\begin{array}{c}\text { After impl. } \\
\text { (Dece }\end{array}$ & At oct-2007) & Difference \\
\hline $\begin{array}{c}\text { Cross } \\
\text { sectional } \\
\text { area }\end{array}$ & $4 \mathrm{~m} 2$ & $2.4 \mathrm{~m}^{2}$ & $1.9 \mathrm{~m}^{2}$ & 2.1 \\
$\begin{array}{c}\text { Volume of } \\
\text { soil loss }\end{array}$ & $886 \mathrm{~m}^{3}$ & $607 \mathrm{~m}^{3} / \mathrm{yr}$ & $480.7 \mathrm{~m}^{3} / \mathrm{yr}$ & $471.8 \mathrm{~m}^{3} / \mathrm{yr}$ \\
$\begin{array}{c}\text { Volume of } \\
\text { soil loss }\end{array}$ & $\begin{array}{c}0.04 \mathrm{~m}^{3} / \mathrm{m} \\
2\end{array}$ & $0.03 \mathrm{~m}^{3} / \mathrm{m}^{2} / \mathrm{y}$ & 0.02 & $0.02 \mathrm{~m}^{3} / \mathrm{m}^{2} / \mathrm{yr}$ \\
per meter \\
equiv.
\end{tabular}

The initial volume of soil lost from the gully before implementing the structure was $886 \mathrm{~m}^{3}$ and reduced to $607 \mathrm{~m}^{3} /$ yrand $480.7 \mathrm{~m}^{3} /$ yrat the end of first and second year respectively. As the above table shows, the introduced technology reduced the cross-sectional area and soil loss of the gully by more than half, which shows the soil and water conservation potential of locally available materials for gully rehabilitation.

\subsubsection{The chemical properties of the soil in the gully}

Table 2: Chemical properties of soil at selga-19.

\begin{tabular}{ccccccc}
\hline Site & \multicolumn{5}{c}{ Parameters } \\
\hline Selga-19 & PH & OC\% & N\% & P & K & CEC \\
At first & 6.96 & 3.6 & 0.336 & 10.43 & 1.7185 & 21.6 \\
$\begin{array}{c}\text { year } \\
\text { At end } \\
\text { of } \\
\text { second } \\
\text { year }\end{array}$ & 6.31 & 1.24 & 0.168 & 3.82 & 0.4 & 24.02 \\
\hline
\end{tabular}

Soil sample was collected from gully channel at the depths of $0-15 \mathrm{~cm}$ to evaluate the effect of physical and biological gully rehabilitation methods on soil fertility improvement and reduction of soil loss [7]. As the above table shows, there was reduction of all parameters except CEC and K in the gully channel, which shows the poor fertility status of deposited soil particle at second year. The eroded and deposited soil in front of the structure was poor in nutrient content than that of first year soil particle because of removal of fertile top soil by continuous water erosion. This result showed, declining of the soil fertility status in the drainage basin due to continuous soil erosion over time.

\subsection{Socio-Economic Characteristics of the Sampled Households}

\subsubsection{Sex, Age and Educational status of participant Farmers}

The total of participant households in the study were 17 and selected to collect qualitative data of farmers' perception on potential of brush wood and stone check dam grass on soil and water conservation [8]. All participant farmers were male with the mean age of 44 year ranging from 22 to 66 years. The educational status of the farmer is the key factor for good understanding of their environment and by considering this, education level of the participant farmers was collected. As the study indicates, $50 \%$ of the farmers were illiterate whereas 36.4 and $13.6 \%$ of the farmers have attended their primary and secondary education respectively. As the study reveals, half of participant farmers were noneducated which may in turn affect the awareness of the community on soil erosion and its effect.

\subsubsection{Perception, acceptance and adoption of the farmers on using bamboo with stone check dam to manage gully}

\begin{tabular}{llcc}
\hline No. & Questions for perception evaluation & \multicolumn{2}{c}{$\begin{array}{c}\text { Answer of } \\
\text { respondents (\%) }\end{array}$} \\
\hline & & Yes & No \\
1 & Problem of soil erosion on their farm land & 100 & \\
2. & Can soil erosion be reduced & 86.4 & 13.6 \\
3. $\quad \begin{array}{l}\text { Have you ever discussed and draw } \\
\text { potential solution for soil erosion problem } \\
\text { of your area }\end{array}$ & 36.4 & 63.6 \\
4. $\begin{array}{l}\text { Do you know about SWC technologies } \\
\text { before }\end{array}$ & 22.7 & 77.3 \\
5. $\begin{array}{l}\text { Have you ever participated on } \\
\text { demonstration and field days of SWC } \\
\text { technologies before? }\end{array}$ & & 100 \\
& &
\end{tabular}

Table 4: Perception parameters

\begin{tabular}{lll}
\hline No & Perception parameters & Respondents (\%) \\
\hline
\end{tabular}

1. Severity of soil erosion on their farm land

Severe

Moderate

2. Minor

Water erosion type on their farmland

Sheet

Rill

Gully

3. Gully

Soil erosion change over time

Highest

Medium

4. Low

What the effect of soil erosion on your farm land

Loss of fertile top soil

5. Yield reduction

What the impact rate of soil erosion on

crop production

Large decrease

Moderate decrease

Moderate increase

Large increase

The participant farmers were interviewed with the aim of assessing the perception of farmers on presence of soil erosion, severity, erosion type, effect and its rate of change over time on agricultural land. Based on this, all of the farmers were mentioned the presence of soil erosion problem on their agricultural land whereas $86.4 \%$ of the farmers were confident that the problem can be reduced by using different soil and water conservation technologies where as $13.6 \%$ of them were not. Most of the farmers were not ever discussed, know, and participated on demonstration of soil and water conservation before. As the result of the interview showed, $77.3 \%$, $18.2 \%$, and $4.5 \%$ of the farmers were affected by rill, sheet and gully erosion respectively. But, the rate of soil erosion is increasing over time and affecting the farmers by eroding the fertile top soil there by reducing their productivity.

3.2.3.1 Indicators of farmer's acceptance of using bamboo with stone check dam to manage gully

\subsubsection{Farmers perception on soil erosion.}

Table 3: Farmer's perception on soil erosion. 
Table 5: Farmer's acceptance on soil erosion.

\begin{tabular}{|c|c|c|c|}
\hline No. & $\begin{array}{l}\text { Questions for acceptance } \\
\text { evaluation }\end{array}$ & $\begin{array}{c}\text { Answer of } \\
(\%)\end{array}$ & respondents \\
\hline & & Yes & No \\
\hline 1 & $\begin{array}{l}\text { Did you know/used bamboo with } \\
\text { stone check dam to manage gully } \\
\text { before }\end{array}$ & 22.7 & 77.3 \\
\hline 2. & $\begin{array}{l}\text { Is bamboo with stone check dam is } \\
\text { effective in arresting soil erosion }\end{array}$ & 95.5 & 4.5 \\
\hline 3. & $\begin{array}{l}\text { Do you believe that bamboo with } \\
\text { stone check dam has the potential } \\
\text { to improve gully productivity }\end{array}$ & 95.5 & 4.5 \\
\hline
\end{tabular}

The acceptance of bamboo with stone check dam to manage gully and its potential on soil and water conservation had also been assessed by interviewing the farmers. Most of the farmers (77.3\%) didn't ever use the technology where only $29.4 \%$ of them had its slight information prior to the experiment. After intervention, all of the farmers ratified the effectiveness of the check dam on arresting soil erosion and $95.5 \%$ of the farmers believe that the gullied land can be changed to productive land by supplementing the physical structure/check dam with different biological measures.

\subsubsection{Indicators of farmers adoption of using bamboo with stone check dam to manage gully}

Table 6: Farmers adoption on soil erosion.

\begin{tabular}{cccc}
\hline No. & Questions for adoption evaluation & $\begin{array}{c}\text { Answer of } \\
\text { respondents (\%) }\end{array}$ \\
\hline 1 & $\begin{array}{c}\text { Do you have the plan to manage and } \\
\text { maintain the check dam }\end{array}$ & 100 & No \\
2. $\quad \begin{array}{c}\text { Do you have plan/intention to implement } \\
\text { the check dam on the rest of your plots }\end{array}$ & 100 \\
3. $\quad \begin{array}{c}\text { Do you believe that implementing SWC } \\
\text { technology is the farmers responsibility } \\
\text { 4. Should the farmers be paid for }\end{array}$ & 100 \\
$\quad$ implementing and maintaining of SWC in \\
their farms
\end{tabular}

It is obvious that the end users of agricultural research are the farmers and other stake holders. Based on this, the willingness of the farmers to adopt and disseminate bamboo with stone check dam technology to manage gully had also been assessed and all of the farmers had the willing to implement on the rest of their plot, to maintain the check dam and believe implementing different soil and water conservation as their responsibility [9]. But, $18.2 \%$ of the farmers believe as they should be paid for implementing and maintaining soil and water conservation which was related with the land policy of Ethiopia (the land belongs to the government) where as $81.8 \%$ of them had the believe of government shouldn't pay for the farmers. Generally, the assessment of farmers adoption showed.

\section{CONCLUSION}

The result obtained from this study indicated the conservation/rehabilitation potential of using bamboo with stone check dam to manage gully. Beside this, the study also created awareness and motivation among farmers about gully and its control. The fertility status of deposited soil was decreased because of continuous removal fertile soil layer by water erosion from the farm land. So, this can be improved by other fertility enhancement methods especially organic fertility improvement measures on the upstream and within the drainage area of the gully to improve both soil fertility and erosion control. Not only that, organic soil fertility enhancement methods are also used to improve the structure/aggregation of soil and increase the permeability of the soil thereby reduce the runoff generation within the drainage. Thus, the farmers and other stakeholders should have to use locally available materials which are cheap and effective to rehabilitate gully and had brought radical change for both gully depth and cross-sectional area. Also using and disseminating locally available materials for gully rehabilitation technology is another assignment of the participant farmers and experts to nonparticipant farmers.

\section{REFERANCES}

[1] AlemuMekonnen, N.D. 2008. Report on vetiver Grass Technology Programme. Integrated Food Security Project.Amhara Regional State Ethiopia www.vetiver.org ETH_eithopia.htm accessed on November 6, 2008.

[2] Menna, A., Getnet, F., Midega, T., and Zeleke, Y. 2007. Assessment of Indigenous Soil Conservation Practices/Materials in Metekel Zone. Unpublished.

[3] FA0.1986. High lands reclamation Study - Ethiopia. Final report, volumes 1 and 2. Food and Agriculture Organization, Rome.

[4] Herweg, K., and Stillhardt, B. 1999. The variability of soil erosion in the High lands of Ethiopia and Eritrea. Research Report 42. Centre for Development and Environment University of Berne Switzerland.

[5] Hurni H. 1986. Guidelines for development agents on soil conservation in Ethiopia. Soil Conservation Research Project. Community Forests and Soil Conservation Development Department, Ministry of Agriculture Addis Ababa Ethiopia.

[6] Moeyersons, J. 2001. Deforestation, gully development and desertification in sub-Saharan tropical and subtropical Africa. Poster presented at Second International Conference on Tropical Climatology, Meteorology and Hydrology, Brussels, 12-14 December 2001.

[7] Haregeweyn, N., Poesen, J., Nyssen, J., Verstraeten, G., de Vente, J., Govers, G., Deckers, J., and Moeyersons, J. 2005. Specific sediment yield in Tigray-Northern Ethiopia: Assessment and semi quantitative modelling. Geomorphology, 69 (1-4), 315-331.

[8] Nyssen, J. 1995. Soil erosion in the Tigray Highlands (Ethiopia): I. Natural and human environment in its relationship to soil erosion. GeoEco-Trop Journal, 19 (1-4), 51-82.

[9] Nyssen, J., Moeyersons, J., Poesen, J., Deckers, J., Mitiku, and Haile, 2002. The environmental significance of the remobilization of ancient mass movements in the Atbara-Tekeze headwaters, Northern Ethiopia. Geomorphology, 49 (3-4), 303-322. 